\title{
THE OCCURRENCE OF MARINE ORGANISMS - IN BALLAST WATER OF SHIP VISITING COLOMBO HARBOUR
}

\author{
S.A.M.A.I.K. Senanayake ${ }^{1 *}$, R.R.M.P.K. Ranathunga ${ }^{1}$, A.J.M. Gunasekara ${ }^{2}$, N. \\ Priyadarshana $^{2}$ \\ ${ }^{1}$ Department of Zoology, Faculty of Applied Science, University of Sri Jayewardenepura, Sri Lanka \\ ${ }_{2}^{2}$ Marine Environment Protection Authority, Sri Lanka. \\ E-mail-senanayakeindunil@yahoo.com, Tel-++ 94773016847
}

\begin{abstract}
Ballast water is a major source of biological invasions around the globe. More than 4500 bulk carriers, cargo vessels and oil tankers arrive to Colombo harbor annually and they discharge a large amount of ballast water in Sri Lankan marine environment. Present research was to study the occurrence of marine organisms in the ballast water of ships visiting Colombo harbour. Ballast water samples were taken from ships visited to Colombo harbor from different ports in Indian Ocean. The species densities were recorded. In addition biological oxygen demand, chlorophyll-a, conductivity, dissolved oxygen, nitrate, $\mathrm{pH}$, orthophosphate, salinity, and temperature were measured in the sample. The vital status (live and dead) of the zooplankton species studied was ascertained using neutral red staining techniques. Thirty-three plankton species were recorded in ballast water samples which included fourteen copepods, eight dinoflagllates, eight diatoms, one protozoan, one rotifer, and one mollusc. Highest density was recorded for Thalassionema sp. and lowest density was recorded for unidentified species belong to family Tintinnidae and gastropod veliger larvae. Ceratium furca, Ceratium fusus, Peridinium sp., Protoperidinium grande, Protoperidinium obtusum, and Protoperidinium robustum were the six species of potentially harmful red tide forming dinoflagllates which were recorded during the study. Neutral red staining technique revealed that there were no live zooplankton species in the ballast water samples. According to the Pearson Correlation there were strong positive linear relationships between species density with nitrate $\left(r^{2}=0.845\right)$ and orthophosphate $\left(r^{2}=0.800\right)$ levels and also $\mathrm{pH}\left(\mathrm{r}^{2}=0.694\right)$ had slightly positive linear relationships with species density. The temperature $\left(\mathrm{r}^{2}=-0.758\right)$ had negative linear relationship with species density.
\end{abstract}

Keywords: ballast water, Colombo harbor, plankton species, staining technique, physico-chemical parameters

\section{INTRODUCTION}

The global scale movement of ships has resulted in a massive transfer of freshwater and marine organisms to the surrounding water (National Research Council, 1996). Ships are a leading source of biological invasions in coastal ecosystems (Carlton, 1985, Ruiz et al., 2000, Endresen et al., 2003, Hayes and Sliwa, 2003). The subsequent discharge of ballast water results in many organisms being released at ports-of-call or in transit, creating numerous opportunities to establish non-native populations (McGee, 2006). The maintenance of ballast water becomes critical during loading and unloading when ballast must be pumped in/out to avoid stresses as a hold is emptied or filled (Eamen et al, 2008).

As the extent of commercial vessel traffic varies considerably among ports, risk of invasion in ports' can fluctuate depending on the frequency and volume of ballast water it receives (Smith et al., 1999). In addition, variability among vessel types, source regions, voyage season, routes and durations can alter the types, numbers and viability of organisms being transported (Verling et al., 2005).

The risk of species introductions with de-ballasting is a source of considerable concern, because many of the organisms that are passed through ballast water intakes. These ballast waters are

Proceedings of the 15 $5^{\text {th }}$ International Forestry and Environment Symposium, 26-27 November 2010.

Published by Department of Forestry and Environmental Science, University of Sri Jayewardenepura, Sri Lanka. 
transported over long distance. The biota transferred through ballast water worldwide is thought to exceed 10,000 species daily (Flagella, 2007). The viability of introduced species in recipient waters can provide important information for categorizing the potential threats from foreign species found in international commercial ships entering ports (Kang et al., 2010).

Non indigenous vertebrates' larval and egg stages, invertebrates, plants' life stages, algae, bacteria and viruses can all be transported as contents of ships' ballast tanks or cargo holds. Once introduced, these species may do significant harm to marine environments, and local economies (Horm et al., 2008). Cholera (Vibriocholera), Cladoceran water flea (Cercopagis pengoi), mitten $\mathrm{crab}$ (Eiocheir sinensis), toxic algae (red/ brown/ green tides) various species, round goby (Neogobius melanostomus), North American comb jelly (Mnemiopsis leidyi), North Pacific seastar (Asterias amurensi), zebra mussel (Dreissena polymorpha), Asian kelp (Undaria pinnatifida) and European green crab (Carcinus maenu) are the most common invasive species via ballast water (IMO, 2003).

The Colombo Harbor is the major port in Sri Lanka. It serves as an important terminal in Asia due to its strategic location in the Indian Ocean. Present study was carried out in Colombo harbor, to do a quantitative analysis of plankton sampled from ballast waters with a variety of foreign port sources. The objectives were to (1) study of the occurrence of marine organism of the ballast water visiting Colombo harbor; (2) develop a method for distinguish dead and live zooplankton in marine waters; (3) identify the variation of each ship with respective to the species density. And (4) identify the variation of each species with respect to physical, chemical and biological parameters.

\section{MATERIALS AND METHODS}

\subsection{SHIP SELECTION AND SAMPLING}

Ballast water samples were taken mainly through manholes. Sampling was restricted to four ships arrived to Colombo harbor in Sri Lanka. One was an oil tanker and others were cargo vessels. Ballast water was collected from side ballast tankers of ships. Three samples were collected in each ship.

Table 2.1: The sampled ships \& their last ballasting regions

Ship Last ballasting region

\begin{tabular}{ll}
\hline Ship 1 & Chiththogon Harbor \\
Ship 2 & Mid Indian ocean \\
Ship 3 & South Indian coastal waters \\
Ship 4 & Klang port in Malaysia \\
\hline
\end{tabular}

Sampling for physico-chemical parameters and chlorophyll-a were done using standard sampling method. Approximately 200 liter of ballast water was filtered through $55 \mu \mathrm{m}$ plankton net. Then the samples were fixed with lugol's solution.

\subsection{LABORATORY ANALYSIS}

Temperature (Philips Harris, thermometer), pH (340 / WTW), conductivity (330 / WTW), salinity (ATAGO/ S/Mill-E Hand refract meter), were measured by using meters. Dissolved oxygen $(\mathrm{mg} / \mathrm{l})$, and biological oxygen demand $(\mathrm{mg} / \mathrm{l})$ were measured by using Winkler method. Nitrite $(\mathrm{mg} / \mathrm{l})$, orthophosphate $(\mathrm{mg} / \mathrm{l})$ and Chlorophyll-a were measured by using standard methods (Silva et al, 1996). Plankton identification was carried out by using Microscope Image Projecting System (MIPS) and plankton guide. 
Proceedings of the 15 $5^{\text {th }}$ International Forestry and Environment Symposium, 26-27 November 2010. 


\begin{tabular}{|c|c|c|c|c|}
\hline & & & & \\
\hline & Ship 1 & Ship 2 & Ship 3 & Ship 4 \\
\hline \multicolumn{5}{|l|}{ Copepod } \\
\hline Acrocalanus sp. * & 667 & 500 & 500 & 667 \\
\hline Calanopia sp. & 333 & 333 & 0 & 333 \\
\hline Calanus sp. * & 500 & 500 & 667 & 333 \\
\hline Euchaeta sp & 333 & 0 & 333 & 0 \\
\hline Isias sp. * & 333 & 833 & 667 & 500 \\
\hline Isias tropica & 667 & 333 & 167 & 167 \\
\hline Microsetella sp. & 0 & 333 & 0 & 333 \\
\hline Paracalanus parvus & 833 & 333 & 333 & 0 \\
\hline paracalanus sp. & 0 & 667 & 500 & 167 \\
\hline Pseudodiaptomus sp. & 500 & 0 & 500 & 167 \\
\hline Temaro sp. & 333 & 167 & 167 & 0 \\
\hline unidentified calanoid copepod $*$ & 167 & 0 & 0 & 500 \\
\hline unidentified nauplius larvae & 833 & 667 & 833 & 667 \\
\hline $\begin{array}{l}\text { unidentified crustacean larvae } \\
\text { Dinoflagellates }\end{array}$ & 500 & 0 & 500 & 0 \\
\hline Ceratium furca $*^{+}$ & 666 & 667 & 500 & 333 \\
\hline Ceratium fusus $*^{+}$ & 167 & 167 & 667 & 667 \\
\hline Ceratium tripos & 667 & 500 & 0 & 0 \\
\hline 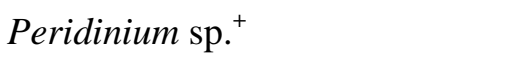 & 833 & 1000 & 500 & 0 \\
\hline Prorocentrum sp. * & 167 & 333 & 167 & 167 \\
\hline Protoperidinium grande ${ }^{+}$ & 667 & 0 & 0 & 500 \\
\hline Protoperidinium obtusum $^{+}$ & 0 & 333 & 667 & 167 \\
\hline Protoperidinium robustum $^{+}$ & 333 & 167 & 667 & 167 \\
\hline \multicolumn{5}{|l|}{ Diatoms } \\
\hline Biddulphia mobiliensis & 1000 & 1000 & 500 & 333 \\
\hline Chaetoceros sp. & 0 & 167 & 0 & 167 \\
\hline Coscinodiscus sp. * & 1000 & 500 & 667 & 167 \\
\hline Navicula sp. & 0 & 167 & 0 & 500 \\
\hline Odontella sp. & 0 & 167 & 0 & 167 \\
\hline Pleurosigma sp. $*$ & 667 & 333 & 333 & 167 \\
\hline Thalassionema nitzschoides & 0 & 667 & 500 & 167 \\
\hline Thalassionema sp. * & 1500 & 500 & 500 & 833 \\
\hline Protozoa & & & & \\
\hline
\end{tabular}

* Specie were common in all ships.

${ }^{+}$Species known to form red tides.

\subsection{WATER QUALITY PARAMETERS}

Table 3.2: Physico-chemical \& biological parameters 


\begin{tabular}{|c|c|c|c|c|c|}
\hline Parameters & Units & Ship 1 & Ship 2 & Ship 3 & Ship 4 \\
\hline $\begin{array}{l}\text { Biological Oxygen } \\
\text { Demand }\end{array}$ & $\mathrm{mg} / \mathrm{l}$ & $0.18+0.01$ & $0.17+0.02$ & $0.23+0.01$ & $0.23+0.03$ \\
\hline Chlorophyll a & $\mathrm{mg} / \mathrm{m} 3$ & $0.67+0.47$ & $0.13+0.04$ & $0.11+0.04$ & $0.13+0.05$ \\
\hline Conductivity & $\mu \mathrm{S} \times 10^{3}$ & $48.43+1.00$ & $51.03+0.05$ & $50.57+0.04$ & $44.7+0.07$ \\
\hline Dissolved Oxygen & $\mathrm{mg} / \mathrm{l}$ & $4.58+0.04$ & $4.63+0.03$ & $4.60+0.07$ & $4.61+0.05$ \\
\hline Nitrate & $\mathrm{mg} / \mathrm{l}$ & $0.02+0.00$ & $0.01+0.00$ & $0.01+0.00$ & $0.01+0.00$ \\
\hline Orthophosphate & $\mathrm{mg} / \mathrm{l}$ & $0.25+0.00$ & $0.09+0.00$ & $0.18+0.00$ & $0.05+0.00$ \\
\hline $\mathrm{pH}$ & & $7.62+0.02$ & $7.73+0.16$ & $7.64+0.01$ & $6.82+0.16$ \\
\hline Salinity & $\%$ & $30.00+0.00$ & $32.00+0.00$ & $31.00+0.00$ & $30.00+0.00$ \\
\hline Temperature & ${ }^{\circ} \mathrm{C}$ & $30.00+0.00$ & $30.00+0.00$ & $30.00+0.00$ & $31.00+0.00$ \\
\hline
\end{tabular}

According to the Pearson correlation there were strong positive linear relationships between species density with nitrate $\left(\mathrm{r}^{2}=0.845, \mathrm{p}=0.001\right)$ and orthophosphate $\left(\mathrm{r}^{2}=0.800, \mathrm{p}=0.002\right)$ and $\mathrm{pH}$ $\left(\mathrm{r}^{2}=0.694, \mathrm{p}=0.012\right)$ had slightly positive linear relationships with species density. The temperature $\left(r^{2}=-0.758, p=0.004\right)$ had negative linear relationship with species density.

\subsection{VITAL STATUS OF ZOOPLANKTON}

Staining method to identified live and dead samples showed that the live zooplanktons were colored with red color and dead zooplankton did not show any color change. According to the results, zooplanktons contained in every ship ballast water sample were dead.

\section{DISCUSSION}

Thirty three species of marine organisms were identified. Among them, ten species were common in all the ships sampled, four of them are copepods (Acrocalanus sp., Calanus sp., Isias sp., unidentified copepods), another three are diatoms (Coscinodiscus sp., Pleurosigma sp., Thalassionema sp.), and other three are dinofagellates (Ceratium furca, Ceratium fusus, Prorocentrum sp.).The highest density was recorded for Thalassionema sp. and lowest density was recorded for unidentified family Tintinnidae and gastropod veliger larvae. Pairwise comparison was conducted using Tukey test in order to compare species densities among ships. According to the analysis, ship 4 had lowest density and ship 1 had highest density. Species densities of ship 2 and 3 were not significantly different. These two ship's last ballasting regions were within the Indian Ocean. Water quality parameters were comparatively same in each ballast samples in ship 2 and 3 hence; it can be argued that the species densities were same in ship 2 and 3 . Therefore, differences in species densities in ship 1 and 4 may be related to variations in water quality parameters.

Species composition in ballast water of present study was different from early study of Fernando, 2007. Sixteen additional species were recorded in present study (Calanus sp., Isias sp, Isias tropica, Microsetella sp., Paracalanus parvus, Temaro sp., unidentified nauplius larvae, Ceratium furca, Ceratium fusus, Ceratium tripos, Peridinium sp., Protoperidinium grande, Protoperidinium obtusum, Protoperidinium robustum, Chaetoceros sp., and gastropod veliger larvae).

There was a strong positive linear relationship between mean species density with nitrate and orthophosphate concentrations. The nutrient level of the water was suitable for the survival of the phytoplankton. 
Proceedings of the $15^{\text {th }}$ 
Flagella, M.M., Verlaque, I., Soria, A.,et al, 2007. Macroalgal survival in ballast water tanks, Marine Pollution Bulletin. 54. 1395-1401.

Fernando, M.A.S.T., 2007. A preliminary study on the invasion of the plankton species into Colombo harbor, through the disposal of ballast water, BSc thesis. University of Kelaniya.

Hayes, K.R., Sliwa, C., 2003. Identifying potential marine pests-a deductive approach applied to Australia. Mar. Pollut. Bull. 46. 91-98.

Holm, E.R., Stamper, D.M., Brizzolara, R.A., 2008. Sonication of bacteria, phytoplankton and zooplankton: application to treatment of ballast water. Marine Pollution Bulletin. 56. 1201-1208.

International Maritime Organisation (IMO), 2003. Marine Environmental Protection Committee (MEPC), Draft International convention for the control of management of ships' ballast water and sediments. MEPC 49/2/3, 24 March.

Jayasuriya, A.B., 2009. A guide to the marine plankton gulf of Mannar and Palk Strait. NARA, Sri Lanka. Kang, J.H., Hyun, B.G., Shin, K., 2010. Phytoplankton viability in ballast water from international commercial ships berthed at ports in Korea. Marine Pollution Bulletin. 60. 230-237

Kasturirangan, L.R., 1963. A key for the identification of the most common planktonic copepod of Indian coastal waters. The council of scientific and industrial research, New Delhi.

Mcgee, S., Piorkowski, R., Ruiz, G., 2006. Analysis of Recent Vessel Arrivals and Ballast Water Discharge in Alaska: Toward Assessing Ship-Mediated Invasion Risk,Marine Pollution Bulletin. 52. 1634-1645.

National Research Council Committee On Ships' Ballast Operations, 1996. Stemming the tide: controlling introductions of non-indigenous species by ships' ballast water. National Academy Press, Washington.

Robert, P., 2003. A Guide to the Marine Plankton of Southern California,third ed,UCLA Ocean GLOBE \& Malibu High School.

Ruiz, G.M., Fofonoff, P. W., Carlton, J.T., Wonham, M.J., Hines, A.H., 2000. Invasion of coastal marine communities in north america: apparent patterns, processes, and biases. Annu. Rev. Ecol Syst. 31. 481-531.

Silva, E.I.L., Namarathne, S.Y.,Weerasooriya, S.V.R., Manuweera, L., 1996. Water Analysis-User Friendly Laboratory Field Manual, Sri Lanka. A J Prints, Dehiwala.

Smith, L.D., Wonham, M.J., Mccann, L.D., Ruiz, G.M., Hines, A.H., Carlton, J.T., 1999. Invasion pressure to a ballast-flooded estuary and an assessment of inoculants survival. Biological Invasions. 1. 67-87.

Verling, E, Ruiz, G.M., Smith, L.D., Galil, B., Miller, A.W., Murphy, K.R., 2005. Supplyside Invasion Ecology: Characterizing Propagule Pressure in Coastal Ecosystems. Proceedings of The Royal Society Of London B. 1249-1256. 